Adrian TUDURACHI

Sextil Pușcariu Institute of Linguistics and Literary History

Cluj-Napoca, Romania

adrian.tudurachi@gmail.com

\title{
THE END OF COMEDY. FOR AN ARCHAEOLOGY OF RECONCILIATION IN THE 19th CENTURY ROMANIAN THEATRE
}

Recommended Citation: Tudurachi, Adrian. "The End of Comedy. For an Archaeology of Reconciliation in the $19^{\text {th }}$ Century Romanian Theatre." Metacritic Journal for Comparative Studies and Theory 4.2 (2018): https://doi.org/10.24193/mjcst.2018.6.08

Abstract: The present article analyses the social function of comedy in the age of building the Romanian modern culture, from an ethical perspective. The importance of the social role of comedy is underlined by its unparalleled prominence and productivity as a literary form, even surpassing the novel in this respect. Martha Nussbaum notes that all societies need "the spirit of comedy" in order to manage the disgust in front of what is new, different, unacceptable or simply other. Taking this cue, the analysis follows the topics of social division, the forms of marginalization and disdain, but also the reconciliation strategies featuring in the 19th century Romanian theatre. Specifically, the article details the end of comedy and its evolutions throughout the century. The approach underlines the way in which literary mechanisms and traditions are involved in peace-making and in social resolution, insisting on the consistency between the forms of social relations (friendship, love, solidarity, co-dependency, etc.) and the literary forms at the end of comedy.

Keywords: comedy, 19th century Romanian literature, theatre, literary forms, social forms, modernity.

\section{Comedie și dezgust}

Într-o reflecție din 2013 despre puterea literaturii și a artelor de a determina emoțiile publice, Martha Nussbaum rezuma funcţia comediei prin „gestionarea dezgustului”: 
All societies must also manage two very disturbing emotions: grief and disgust. The former needs to be channeled in ways that promote reciprocity and extend, rather than narrow, compassion; the latter needs to be contained, lest it become an impediment to general concern. All societies, then, need something like the spirit of tragedy and the spirit of comedy - the former shaping compassion and the sense of loss, the latter indicating ways to rise above bodily disgust in a spirit of delighted reciprocity (Nussbaum, Political 201).

Afinitatea comediei cu sfera dezgustului nu trebuie demonstrată. În virtutea unei lungi tradiții, care coboară până în antichitate, în centrul comediei, ca sursă inepuizabilă a efectului comic, stă trupul în detaliile sale respingătoare. Diferitele părți rușinoase ale corpului, emanațiile involuntare sau fluidele, comportamentele înjositoare ori animalice, desfrâul, murdăria etc. contribuie din plin la ceea ce Bahtin numea, vorbind despre Rabelais, „râsul popular milenar” (576). Martha Nussbaum nu vizează însă bogăția inepuizabilă a materialismului corporal, ci implicarea categoriilor „dezgustătorului” în stabilirea unui raport social. Spus simplu, e vorba de capacitatea sa de a stigmatiza: dezgustul e privit ca un mijloc prin care se reglează distanța față de o persoană sau de un grup, un instrument prin care se construiește o relație - evident, de inegalitate, implicând dispreț și desconsiderare - cu ceilalți. Ceea ce ne dezgustă nu e numai un spectacol inepuizabil al cărnii, e și un mod de a izola indivizi, în vederea „purificării” corpului social.

Suportul pe care Martha Nussbaum construiește această interpretare e psihanalitic. Hiding from Humanity: Disgust, Shame, and the Law, o analiză mai veche despre implicarea dezgustului în raționamentele juridice, explică rolul esențial pe care acesta îl joacă în procesele istorice de segregare și excludere a categoriilor vulnerabile din societate. Identificând în dezgust teama universală în fața propriului corp animal și în fața mortalităţii, filosoafa americană prezintă mecanica acestei emoții ca o tendință de a proiecta asupra altora o frică ascunsă, refulată, față de decădere sau de regresie în animalitate. Un corp pe care îl simțim fragil, supus descompunerii și dispariției e transferat prin dezgust spre exterior, și proiectat asupra tuturor prezențelor vulnerabile din comunitate. E o modalitate prin care propria frică e exorcizată, trecând-o în contul celuilalt: un celălalt care poate fi feminitatea, evreitatea, homosexualitatea sau orice altă formă de instanță socială minoritară și dominată. Din această perspectivă, filosoafa americană avertizează că nu proprietăţile unei anumite categorii aflate în marginea societăţii determină 
dezgustul, ci invers. Nu excludem ceea ce e stigmatizat, în raport cu murdăria și impuritatea unui grup social, ci stigmatizăm ceea ce vrem să excludem. Altfel spus, murdăria sau impuritatea sunt doar niște figuri chemate să justifice nevoia de a ține la distanță ceea ce nu putem controla și asimila: schimbarea, alteritatea, decăderea, moartea. De aici concluzia că dezgustul e o forță socială care trebuie să fie controlată şi contracarată: „the really civilized nation must make a strenuous effort to counter the power of disgust, as a barrier to the fully equality and mutual respect of all citizens" (Nussbaum, Hiding 116).

Cum poate comedia să intervină în acest joc social al „dezgustătorului”? Martha Nussbaum subliniază două modalități. Prima vizează efectul de inegalitate pe care îl antrenează dezgustul. Spiritul comediei, pe care filosoafa americană îl identifică în piesele lui Aristofan, implică amestecul claselor şi substituția stigmatelor. Comedia va arăta că oricine poate fi desconsiderat, îl va schimba pe prinț în cerșetor, și va inventa noi dispozitive de substituire și de inversare a pozițiilor sociale, prin care servitorul poate lua locul stăpânului. Prin capacitatea de a răsturna sensul stigmatului și de a generaliza utilizarea lui, de a trata repulsia ca un joc de combinații, comedia deconstruiește reprezentarea unei inegalități substanțiale, determinate de natura însăşi a indivizilor sau a grupurilor din care fac parte. Cea de-a doua operează asupra suportului material al dezgustului, adică asupra raportului cu corporalitatea. În esență, exemplele pe care le dă Martha Nussbaum scot în evidență capacitatea comediei de a banaliza expresiile rușinoase ale trupului: personaje preocupate de nevoile cotidiene ale corpului, conștiente de fragilitatea lor, suferind de boli, de bătrânețe sau de foame, și lăsând să treacă toate aceste frământări triviale înaintea aspirației la glorie sau nemurire. Obișnuindu-l pe spectator cu decăderea ființei de carne, comedia contribuie la acceptarea propriei vulnerabilități - şi, prin urmare, şi a vulnerabilităţii altora. Însă ce mi se pare important în această interpretare e faptul că nu vizează negarea dezgustului, nici dispariția categoriilor „dezgustătorului”. În fața unui text din Whitman care vorbește despre o utopică egalitate a tuturor corpurilor, Martha Nussbaum se întreabă dacă putem să aspirăm la o lume în care nicio prezență să nu mai fie dezgustătoare:

No real society has triumphed over disgust [...]. Nor should we hastly conclude that such a society is even an ideal norm we should endorse. Should human beings really try 
to rid themselves of disgust insofar as they possibly can, in every aspect of the fabric of our lives? (Nussbaum, Hiding 120).

Din perspectiva filosoafei americane, universul comediei rămâne populat până la capăt de personaje dezgustătoare, de vicii scârboase, de categorii sociale discreditate, de tipuri umane insuportabile, de instanțe pe care comunitatea nu le poate tolera. Știind să vorbească despre toate acestea, colecționându-le și fiind sensibilă la prezența lor, calibrându-se ca un seismograf fin la cele mai subtile semne ale desconsiderării, comedia nu promite să le facă să dispară, ci să le administreze. De aici modul economic şi managerial în care Martha Nussbaum gândește angajarea comediei. Instalându-se într-un câmp al distanțelor sociale, ea are capacitatea de a le mobiliza şi de a le redispune neîncetat. Ceea ce în societate e raport fix, în comedie e pus în mişcare printr-un joc al apropierii și depărtării, al simpatiei şi antipatiei, al stabilirii de reciprocități și simetrii. În acest sens, comedia „gestionează dezgustul”: gândește raporturile de desconsiderare, le face vizibile și le reorganizează.

E mai greu decât ar putea să pară să urmărim această funcție socială a comediei în cultura română. Pentru că interpretarea teatrului ca instrument prin care o societate gestionează emoțiile din gama dezgustului implică o disponibilitate de percepere și de înțelegere a codurilor reconcilierii. Or, în această privință, bilanțul culturii române e mai degrabă negativ. Avem chiar un exemplu ilustru: în 1975, întrun eseu publicat în clandestinitate la Paris, N. Steinhardt a propus o interpretare a Scrisorii pierdute pe baza iertării. Gestul pe care Zoe Trahanache îl face față de Caţavencu spre finalul actului al IV-lea absolvindu-l de vina de a fi acţionat împotriva ei e privit ca definitoriu pentru structura însăşi a umanităţii caragialiene. Steinhardt comentează un schimb de replici „Iartă-mă” (Cațavencu) / „Te iert” (Zoe Trahanache), care, chiar dacă se datorează parțial unei „memorii false”, e în sine elocvent pentru toposul pe care criticul îl pune la baza interpretării. Felul în care a fost receptată această lectură nu lasă niciun echivoc. Chiar dacă eseul a fost difuzat în România după căderea regimului comunist, în 1995, când proiectul său etic și spiritual putea să fie discutat fără rezerve, critica românească a considerat că reconstrucția piesei pe baza iertării era nu numai falsă, ci şi inutilizabilă. ${ }^{1}$ Şi astfel,

\footnotetext{
${ }^{1}$ „N. Steinhardt trăiește cu iluzia de a fi descoperit acest secret. Dar cele susținute de eseist despre $O$ scrisoare pierdută şi în special despre actul al IV-lea al comediei confirmă încă o dată capcanele ambiguității” (Fanache 247-248).
} 
singura interpretare a reconcilierii în opera lui Caragiale rămâne cea mai faimoasă lectură greşită a Scrisorii pierdute.

De ce nu ne interesează reconcilierile? Cred că cea mai simplă explicație e că prin tradiție am văzut în comedie un instrument de pedeapsă. Cercetarea teatrului românesc în secolul al 19-lea s-a axat pe componenta de critică a moravurilor, interpretând discursul comic exclusiv în cadrul unei acțiuni de moralizare şi de condamnare a viciilor sociale. „Teatrul războiește vițiul”, spunea Heliade Rădulescu în 1836. Această afirmație, reluată de atâtea ori în secolul al 19-lea, determină funcția socială a comediei în cadrul unui scenariu care e în acelaşi timp naționalist și progresist, implicând aspirația spre un corp social superior obținut prin ameliorarea vieții sale morale. Comedia a fost gândită de contemporani ca un act de educare a națiunii bazat pe iluzia perfectibilităţii, pe ritualurile de purificare şi excludere, nu pe acelea de acceptare. Să reformulez simplu în relație cu tema pe care o discut aici: comedia a fost tratată ca parte a procesului de stigmatizare, nu a gestionării lui. E aproape inutil să adaug că în acest scenariu dezgustul - față de vicii şi față de „răul” social - nu era o forță care trebuia controlată, ci una care trebuia exploatată. „The goal of civilising manner is to repress the disgusting" subliniază William Miller (182), reluând teza celebră a lui Norbert Elias despre importanța dezgustului în cadrul proceselor de civilizare. De ce oamenii secolului al 19-lea au avut nevoie de o asemenea perspectivă asupra comediei e uşor de înțeles. Trebuie însă să ne întrebăm de ce istoria noastră literară a rămas captivă acestui scenariu², mult după ce cadrul lui de justificări a devenit desuet.

$\mathrm{Nu}$ cred, de aceea, că înțelegerea funcției sociale a comediei se poate face fără o reevaluare a cadrului de interpretare. Ca să regândim comedia în raport cu temele diviziunii sociale avem nevoie, în primul rând, de o definiție sociologică a conflictului comic. Trebuie să acceptăm că distribuția conflictelor nu se face dihotomic şi maniheist, în funcţie de rău şi bine, de viciu şi virtute. Nu există un sens educativ al stigmatului, nu putem spune că anumite forțe, datorită impactului lor social, devin ținta dezgustului și a excluderii. Desconsiderarea poate viza instanțele novatoare sau pe cele conservatoare, pe tineri sau pe bătrâni, pe cei la modă sau pe cei care au alunecat în afara ei, pe soție sau pe bărbat, pe țăran sau pe boier. Trebuie să depășim „evidențele” morale și, uneori, chiar să ignorăm ceea ce autorii din epocă erau dispuși

2 Un exemplu în acest sens e chiar cea mai importantă sinteză a secolului al 19-lea în literatura română, aceea a lui Paul Cornea (439-441). 
să susțină despre funcția socială a propriilor opere. Reflecţia sociologică restituie realitatea acestui conflict, care, dincolo de ceea ce pretinde că face - „războiește vițiul" -, sfârșește prin a stabili un raport de inegalitate și are multiple efecte de marginalizare socială. În al doilea rând, avem nevoie să ne eliberăm de perspectiva optimistă asupra soluționării conflictului comic. Nu, nu totul se rezolvă la final. Din perspectivă etică, dacă vorbeşte despre viciu şi despre vinovăţie, comedia nu o face pentru a mântui, ci pentru a găsi o cale de acceptare a distanței pe care acestea o presupun. Comedia nu absolvă, doar justifică. De aceea Giorgio Agamben observa într-o reflecție asupra Divinei comedii („Comedy”), construind o simetrie între cele două forme care au marcat relația multimilenară a societății umane cu vinovăția: dacă tragedia e vina celui just și drept, comedia e îndreptățirea celui vinovat. Iar din acest punct de vedere trebuie să acceptăm că gestiunea diviziunilor sociale nu înseamnă nici curățarea caracterelor, nici „,salvarea” lor. În sfârșit, această recalibrare a interpretării implică o refocalizare asupra finalului comediei. Deznodământul, una dintre cele mai codificate zone ale literaturii, ale cărei tradiții străbat antichitatea, Renașterea, epocile revoluționare până la happy-end-ul hollywoodian, este locul prin excelență al reconcilierii. La final, actorii conflictului se împacă. Însă dincolo de această generalitate, modurile reconcilierii sunt infinit variabile, în funcție de dispozitivele şi tradiţiile culturale, şi mai ales în funcţie de utilizarea lor. Nu există o soluție simplă, totală și mecanică, de reducere a distanțelor din sânul unei societăți: în realitate, finalul comediei organizează etaje diferite de integrare, lasă pe dinafară personaje sau poate pur şi simplu să eşueze. Nu putem să presupunem o rezolvare stereotip, ci doar să observăm felul în care se articulează trei elemente: oferta de forme literare incluzând atât tradițiile universale, cât şi inventivitatea estetică locală, obiectivul moral de gestionare socială a dezgustului și gravitatea „vinovăției”, percepția socială a stigmatului și a posibilităţii sale de reintegrare.

Ceea ce mi se pare limpede și stimulant în abordarea etică propusă de Martha Nussbaum e posibilitatea unei repoziționări în faţa fenomenului de emergență masivă a comediei în istoria literaturii române în secolul al 19-lea. Putem rediscuta contractul social care a justificat explozia comediei și putem încerca să înțelegem în funcție de el dinamica extraordinară a comicului într-un moment în care toate celelalte ipostaze ale literaturii erau abia schițate. De ce începătorii literaturii române au avut nevoie de atâtea comedii? Sau, aşa cum ne permite Martha Nussbaum să 
reformulăm întrebarea: ce dezgust trebuia controlat și domesticit, ce distanțe sociale trebuiau îmblânzite, ce excluderi trebuiau reintegrate?

\section{Violența stigmatului și eșecul reconcilierii}

S-au folclorizat de multă vreme figurile desconsiderării din O noapte furtunoasă: „un ăla”, „maţe fripte”, „coate-goale”, „bagabontul”, „moftangiul”, „papugiul”. Jupân Dumitrache își manifestă disprețul față de Rică Venturiano și, prin violența calificării verbale, încearcă să stabilească o distanță socială imposibil de transgresat. Cu un asemenea personaj nu se discută, nu se schimbă politețuri în ceremonialul social și, desigur, nu se acceptă relații de familie. În fond, în cazul lui nu e tolerată nici măcar angajarea publică a conflictului. „Eu, de! Negustor, să mă pui în poblic cu un coategoale”, ține să sublinieze de mai multe ori Jupân Dumitrache (Caragiale, Opere 16). Această tehnică din dramaturgia lui Caragiale făcea ecou unei tradiții teatrale mult mai vechi și forme ale dezgustului apar deja în primele piese româneşti păstrate. $\mathrm{Cu} o$ jumătate de secol mai devreme, găsim apelative, etichete depreciative şi moduri de manifestare ale disprețului față de ceilalți ca parte definitorie a limbajului teatral românesc. În dramaturgia lui Costache Caragiali femeile sunt „turbate”, bărbaţii sunt „târâtoare” sau „gângavi”. Ea îi spune lui „mojic” şi „calic”; el îi întoarce insulta, calificând-o „mojică” și „ticăloasă”. Poeții sunt „o lepră” la Matei Millo, bătrânii sunt „ghiuji” cam peste tot, iar în piesele lui Alecsandri grecii sunt ca lăcustele, un tânăr e o „dihanie”, femeile sunt „lighioi”. Teatrul comic din epocă abundă în expresii ale animalității, ale bolii sau ale stigmatului, proiectate asupra categoriilor care încarnează alteritatea. 3 Aceste forme ale distanței sociale sunt încă și mai bine marcate când în definiția personajului apar conotații rasiale sau de clasă. În Peatra în casă, vodevilul lui Alecsandri din 1847, Leonil dă frâu liber scârbei după ce o sărută din greșeală pe Ioana Țiganca:

\footnotetext{
3 Fără să dezvolt, o să spun că sursa diviziunii sociale în comedia din secolul al 19-lea e strâns legată de procesul de modernizare al societății românești. Accelerarea ritmurilor temporale, rata ridicată de perimare și înnoire a tipologiei sociale, apariția multor îndeletniciri noi și caducitatea ordinii date prin tradiție, emergența unor noi organizări sociale, posibilitatea transgresiunii castelor și a emancipării, toate acestea generează o pluralitate de conduite și de forme de viață care solicită stigmatul. E o societate care se îndepărtează rapid de sine şi care generează reziduuri sociale atât prin noile realități cu care intră în contact, cât și prin propriile realități pe care le abandonează în procesul modernizării. Lexicul dezgustului e hrănit de trei categorii ale diviziunii: una temporală, care cuprinde agenții noului sau pe reprezentanții vechii lumi, una socială, care îi vizează pe țărani și pe servitori, pe boieri și pe proprietari și una etnică, în care intră țiganii, evreii, sau alogenii în general (greci, nemți, francezi etc.).
} 
O! ce foc

M-a trăsnit

Stau pe loc împetrit!

Iubeam un înger, o porumbiță

Şi de la dânsa ceream guriță;

Când vai! În ciudă

Soarta mea crudă

Schimbă pe înger într-o țigancă

Pe porumbiță în trup de stancă

Şi-n loc de miere

Ah! Gustai fiere!

Şi-n loc de buze de verișoară

Sărutai gingaș... un plisc de cioară! (Alecsandri V, 298).

Două decenii mai târziu, în contextul reformelor lui Cuza și a aprinselor dezbateri publice pe care le-au generat, țăranii fac obiectul unor forme explicite ale stigmatului. Prezența lor „insuportabilă” constituie tema vodevilului lui Alecsandri din 1865, Harță răzăşul. Subiectul e în aparență economic. Orăşeanul Bursuflescu, instalat recent la țară, vrea să cumpere şi terenul țăranului cu care se învecinează moşia lui. Însă achiziția şi negocierea sunt animate de pasiuni negative și de un sentiment, explicitat, de repulsie socială. Tarsiţa Garofeasca îi mărturisește lui Bursuflescu:

Nu mai este de trăit

$\mathrm{Cu}$-astfel de vecini mojici

Harță-i de nesuferit

Trebuie alungat de-aici (Alecsandri V, 242).

Puțin mai încolo, îi spune de-a dreptul lui Harță: „Ai înțeles că am nevoie să mă dezbăr de vecinătatea ta?”. Alecsandri nu ratează valența antropologică a acestui conflict, care nu mai vorbește despre pământ, despre relaţii economice sau despre concurența pentru pământ, ci despre o angoasă subconștientă a contagiunii și a contactului cu alteritatea. Țăranul subliniază semnificația reală a conflictului, care se leagă nu de interesul pecuniar, ci de nerecunoașterea lui socială, ca individ cu drepturi egale: „Să te dezbări? Dar ce sunt eu, boală?”. Replica vine ca o confirmare şi 
ca o specificare a acestei afecțiuni prin apropiere de celălalt: „Vătămătură” (Alecsandri V, 243).

Gravitatea acestor expresii ale repulsiei se poate măsura prin efectele lor asupra desfăşurării conflictului. Faptul cel mai surprinzător și mai problematic în acelaşi timp e că manifestările de intoleranță descătuşate în cursul piesei nu se rezolvă la final. $\mathrm{Cu}$ cât coborâm în istoria dramaturgiei noastre, cu atât soluțiile de împăcare sunt mai fragile sau chiar inexistente. Primele comedii nu seamănă propriu-zis cu niște comedii - adică nu se termină cu bine. Iar situațiile de eșec, în care finalul comediei nu rezolvă disensiunea socială, sunt frecvente. Caracterul insolubil al diviziunii sociale se vede chiar în interpretarea „predecesorilor” lui Rică Venturiano. Tânărul de modă nouă, „străinul” care calcă în casă şi strică rânduiala ei patriarhală e o figură definitorie a dezgustătorului şi un leitmotiv al întregii epoci. Până înspre 1850, această prezență se rezolvă prin excluderea definitivă a intrusului din corpul social. Așa se întâmplă la Costache Caragiali, în Doi coțcari sau păziți-vă de răi ca de foc, sau la Constantin Negruzzi, în Cârlanii. Cel mai expresiv în acest sens rămâne finalul piesei lui Costache Facca din 1833, Comodia vremü. Iată condamnarea rostită de stăpânul casei:

\section{Puteți fi orice vă place}

Sau boieri sau militari

Dar fiindcă ici în casă cât oi trăi, poruncesc,

Şi vorbele d-voastră în nimic le socotesc

Ișiți mai curând afară și p-aci să nu mai dați (Primii 110).

Faptul care trebuie observat e că în acest deznodământ care refuză reconcilierea nu sunt antrenați doar „străinii”, ci și membrii familiei. Dezgustul resimțit față de o forță externă, ostilă și amenințătoare, se transferă asupra cercului interior, în care se recunoaşte aceeași pasiune a noutăţii. Comedia se încheie nu numai cu eliminarea factorilor perturbatori din afară, cu o „purificare” în raport cu o intruziune, ci și cu o amputare a familiei. Și abia această extindere a conflictului ne dă măsura eșecului împăcării. În finalul comediei lui Facca, aproape imediat după prigonirea celor doi intruși, vin versurile adresate femeilor din familie, soția și cele două fiice: „Ișiţi și voi cu bontonu, dinainte-mi să periți/ Mergeți mai curând la dracu, la mai mari nu mă siliți” (Primii 110). La fel încheie Costache Caragiali piesa O soare la mahala sau 
amestec de dorințe (1847). Comedia pune în scenă un soț care se luptă cu gustul pentru noutate al soției și cu influența ei asupra fiicei. Conflictul e marcat puternic, cu vorbe grele și cu amenințări de repudiere:

Femeie ticăloasă! [...] Cum nu ți-e rușine ție însăți să mai pretinzi a sta cu mine în căsătorie, netrebnico [...]. Nenorocito, socotești că numai Dealu Mitropoliei poate să desfacă o căsătorie? Te înșeli! Ea este desfăcută din minutul ce s-a rostit acest cuvânt între acei căsătoriți. De astăzi înainte tu nu te mai bucuri decât de ura mea. Poți să te mângâi cu dânsa. Atâta meritezi! (Primii 215).

În final, numai o parte din violența verbală e mântuită printr-un rezolvare fericită. Stăpânul casei acceptă căsătoria tinerilor, își iartă fiica, dar rămâne ferm în condamnarea soției. Ca și în Comodia vremü, familia e iremediabil afectată de descătușarea disprețului și a desconsiderării: „Copiii mei, fiți fericiți! Iar cât pentru Cocoana Măndica, domnii mei, până acum Scărlăteasca, o declar de astăzi înainte în titlu-i părintesc Manolească, oprindu-o d-a se mai iscăli cu numele meu și a-mi purta titlul de femeia mea" (Primii 241).

În jurul acestei dificultăți de a rezolva dezgustul cred că putem construi un sens al întrepătrunderii între literatură și societate în secolul al 19-lea. Ceea ce ne arată situațiile de eșec al reconcilierii e faptul că diviziunea socială nu e nici conjuncturală, nici superficială, destinată unei rezolvări simple. Istoria culturală poate lega aceste cazuri de evoluția percepției noutății și a modernizării de-a lungul secolului al 19-lea; după cum imagologia poate explica unele forme ale intoleranței extreme în raport cu procesul de negociere a imaginii sociale a femeii, a țiganilor, a țăranilor sau a evreilor. E însă important să ținem cont de faptul că eșecul reconcilierii se exprimă printr-un balans între societate și familie, pe tendința de a repercuta diviziunea socială asupra spațiului privat și de a identifica discordia cu actori din interiorul primului cerc al rudeniei: mame, tați, frați, fii, fiice. Cred că trebuie să înțelegem aceste implicații dintr-o perspectivă de filosofie politică. Primii noștri autori de teatru s-au confruntat cu o caracteristică a conflictului social pe care n-au știut să o gestioneze: faptul că diviziunea trăită de o comunitate e „conaturală” reflexului ei familial. Ce se divide într-o societate, fie își are originea într-o ruptură apărută în familie, fie se răsfrânge într-o disensiune familială, creând premisele unei lupte între frați. În mai multe studii dedicate lexicului grec care denumește diviziunea socială, Nicole Loraux („La 
guerre"; La tragédie) a demonstrat că, din punct de vedere filologic, expresiile războiului civil implică angajamentul familial. Reamintind celebra regulă a lui Aristotel că în vreme de conflict în interiorul cetății fiecare membru al unei familii trebuie să își aleagă partea, Loraux arată că „războiul în familie” e celălalt versant al războiului civil. Familia nu stinge conflictul, ci contribuie la interiorizarea lui, apropiindu-l de individ: dezgustul care adâncește discordia în familie e un element fundamental al trăirii diviziunii sociale şi al asumării ei de către corpul social. Pe baza demonstrației lui Nicole Loraux, Giorgio Agamben a încercat să gândească această circulație a conflictului între familie și viața publică ca un prag al „politizării”, esențial pentru funcţionarea democrației în epoca statelor naţionale:

Quand prévaut la tension vers l'oikos et que la cité semble vouloir se résoudre en une famille, certes, d'une nature particulière, la guerre civile fonctionne alors comme le seuil où les rapports familiaux se repolitisent; en revanche, quand c'est la tension vers la polis qui prévaut, et que le lien familial semble se relâcher, alors la stasis intervient pour recodifier en termes politiques les rapports familiax (Agamben, La Guerre 29).

Agamben vede „războiul în familie” ca o compensaţie a unui spațiu public care a fost - prin exces de idealism şi utopie - golit de semnificațiile sale politice. Când națiunea tinde să proiecteze comunitatea ca o mare familie, „războiul în familie” e locul în care dinamica politică și conflictul se restabilesc. Într-o societate al cărei ideal de coeziune e conceput prin extrapolarea fraternității și a consangvinității la nivelul întregului corp social, într-o societate care neagă prin forma ei ideală logica partizană, unde se mai poate reîntemeia politica dacă nu în diviziunea spațiului intim? Alungată din viața publică, politica se refugiază în familie: după ce i s-au interzis marile angajamente partinice, se reinventează în fracturarea infinitezimală a disensiunilor casnice, în care fiecare urăște și e dezgustat de toți ceilalți. Poate că ar trebui, atunci când abordăm ideile și pasiunile naționaliste din prima jumătate a secolului al 19-lea, să corelăm imaginile retorice ale patriei din discursul public cu violentele invective familiale din comedie. Să punem în legătură, ca doi versanți ai aceluiași câmp politic, descătuşarea de ură și dezgust din comediile începutului de drum cu utopiile „poporului”, care proliferează în epoca paşoptistă. Ca și cum meschinăria disprețuitoare a uneia ar contrabalansa idealismul fanfaron al celeilalte. Numai aşa putem înțelege cât de serios era stigmatul comic şi „vinovăţia” pe care el o ilustra. 
I.L. Caragiale va ști mai târziu, în $O$ noapte furtunoasăă să evite această implicație situând figura femeii bovarice și conflictul casnic pe cel de-al doilea cerc al rudeniei (Zița e numai cumnată), eliberând familia de pericolul „războiului civil”. Însă în aceste „rezolvări” nu trebuie să vedem o soluție magică, pentru că îndărătul reconcilierilor persistă conflictul și diviziunea socială, în toată gravitatea sa. În fond, virtuozitatea epocii clasice a dramaturgiei româneşti constă în dispunerea atentă a surselor de conflict social, în camuflarea și naturalizarea desconsiderării. Ceea ce vor învăța autorii de teatru va fi nu bagatelizarea dezgustului, nici rezolvarea lui miraculoasă, ci, în termenii lui Nussbaum, gestionarea lui.

\section{Două forme ale reconcilierii: nunta şi hora}

O să mă opresc asupra a două soluții de reconciliere, una cu tradiție culturală lungă (căsătoria), cealaltă legată de o inovație culturală locală (hora).

Ca dispozitiv dramatic, căsătoria a străbătut mai multe vârste ale literaturii. Modelul receptat în spațiul românesc s-a bazat pe reinterpretarea funcției sociale a căsătoriei în contextul revoluționar european de la sfârşitul secolului al 18-lea, ca simbol al capacității de a depăşi diviziunile generaționale între nou și vechi sau diviziunile sociale între clasele superioare și cele subalterne. În centrul acestei figuri a căsătoriei stă expresia liberului arbitru, afirmat în numele unui drept de „căutare a fericirii”, după expresia din studiul clasic al lui Stanley Cavell despre comedia recăsătoririi (1981). Este vorba de dreptul fiecărui individ de a fi „antreprenorul” propriei existențe și de a-şi construi un destin prin alegeri personale, sustragându-se astfel predeterminărilor sociale, culturale, rasiale etc.; un individ care descoperă, odată cu potențialul împlinirii de sine, și puterea de a schimba ordinea lumii în care trăiește.

În acest cadru, interpretarea căsătoriei în comedia românească din secolul al 19lea tinde să sublinieze natura de dispozitiv a acesteia. Putem constata acest fapt analizând câteva situații din bogata colecție de piese comice ale lui Alecsandri. Harță răzăşul se încheie de pildă cu o căsătorie dublă, una de țărani, cealaltă de boieri. E cea mai simplă rețetă prin care deznodământul amenajează o reconciliere socială: un mariaj la nivelul clasei superioare se oglindește într-o căsătorie în clasele de jos, care implică servitori, țărani sau țigani. Piesa stabilește astfel un paralelism între categoriile sociale, fără să le amestece, fără să șteargă diviziunea, și mai ales fără să implice actul de voință al personajului în transgresiunea faliilor sociale. Mai 
interesant e procedeul din vodevilul Peatra din casă. Acesta prezintă un joc al căsătoriei caleidoscopice, care distribuie perechile aleatoriu în funcție de $\mathrm{o}$ constrângere mecanică, incontrolabilă de către personaje. Cuplul dintre Pâlciu și Marghiolița se formează în ciuda indiferenței lui și, mai ales, a disprețului ei exprimat limpede („Nu-l cunosc... dar mi-a spus Leonil că-i prost de tot” Alecsandri V, 294). Alecsandri îi imaginează pe cei doi închişi din întâmplare în dulap şi numai hazardul de a se găsi în acelaşi spațiu creează aici posibilitatea unei reconcilieri neverosimile. După descoperirea lor în dulap („Ce-mi văzură ochii! Verişoara cu Pâlciu! Închişi într-un dulap! Pân întuneric!” (Alecsandri V, 318), coregrafierea împăcării urmează parcă un ritual, eliminând orice urmă de angajare voluntară:

Franț: Ați auzit? ... faceți cum vă zice el (Silindu-i să-și deie mânele). Dați-vă mânele și ziceți: Noroc să deie Dumnezeu!

Zamfira: (Căutând cu dragoste la Franț). Fie cum vrei monsiu Franț. (Lui Pâlciu). Noroc să deie Dumnezeu!

Pâlciu: Amin (Alecsandri V, 319).

Trebuie observat şi montajul marital din Cinel-cinel, un vodevil din 1858, care implică o relație a țăranului Graur cu un grup de fete de la oraș. Distanța socială și raportul explicit de desconsiderare („Nu vă spuneam eu că țăranii sunt oameni ca și noi”, observă cu candoare una dintre „dame”) sunt depășite, din nou, prin implicarea aleatoriului. Incapabil să facă diferențe, nevrând să supere pe niciuna din fete, după cum mărturisește el însuşi („Pe care s-aleg oare?... toate-mi sunt pe plac! Ş-apoi de-oi alege pe una s-or mâhni celelalte, mititelele! Alecsandri V, 590), protagonistul acceptă să îsii aleagă partenera printr-o serie de probe. Piesa, care evocă printre alte forme ale hazardului şi tragerea la sorți, se încheie cu un concurs cu ghicitori şi un joc de-a „baba-oarba”. Joc, orbire, noroc - toate evocă un proces de alcătuire a cuplului din care a fost eliminată pasiunea și voința individului. Să remarcăm aşadar că nunta, ca soluție de neutralizare a distanței și inegalității sociale, e definită de absența angajării libere a protagoniștilor. Ceea ce vedem în punerile în scenă ale căsătoriei e un corp social inerțial, care participă la reconciliere numai în virtutea unei impuneri exterioare. Și chiar dacă putem distinge între două forme de acțiune ale acestei impuneri, prin constrângere și prin accident, ambele implică în egală măsură deresponsabilizarea individului. 
Spre deosebire de căsătorie, hora e o formă strâns legată de contextul de la 1848. Temă centrală în procesul de redescoperire a tradițiilor populare în cadrul romantismului național, ea face parte din ritualurile sociabilității revoluționare și apare frecvent în practicile asociațiilor revoluționarilor români, în clandestinitate sau în exil. O găsim la Alecsandri în Românii și poezia lor din 1849, în corespondența lui Bălcescu, în numeroase evocări ale emigrației româneşti etc. În teatru apare în comediile lui Alecsandri și ale lui Matei Millo, imediat după 1844. Cu o horă se încheie comedia lui Matei Millo, Însurățeii și mai multe comedii sau vodeviluri ale lui Alecsandri: Iorgu de la Sadagura (1844), Iașii în carnaval (1845), Nunta țărănească (1848). Mesajul unionist și național nu a scăpat nimănui și în epocă a fost unul dintre principalele motive pentru succesul de scenă al unor asemenea reprezentări. Însă trebuie spus că o horă la finalul unei comedii nu e niciodată doar o horă, adică reunirea egală, nediferențiată și nediscriminată a tuturor personajelor. Ea presupune o organizare complexă a scenei, cu mai multe poziții și mișcări, sincronizate sau în tensiune. Iorgu de la Sadagura adună în dansul final aproape toate personajele, cu două excepții. Iată instrucțiunile de executare a scenei: „Toți joc hora, afară de Kiulafoglu care trage ciubuc deoparte; Gahița şi Kleine Schwabe joc valțul împregiurul horei” (Alecsandri VI, 65). Agamemnon Kiulafoglu e un înalt funcționar grec, Gahița Rosmarinovici reprezintă femeia bovarică, Kleine Schwabe, un „neamț sărac”. Evident, sunt cu toții „străini”, prin naștere, prin apartenență etnică sau prin preferințe. Scena horei amenajează o integrare socială etajată, în care participarea la comunitate se face în grade și în stiluri diferite: de la dansul în paralel al horei și al valsului, până la retragerea din mișcare în cazul lui Kiulafoglu. Înțelegem mai bine potenţialul acestei dispuneri în Iaşii în carnaval. Aici scena horei e construită tot pe baza unei distribuții între cei care joacă şi cei care nu. Însă aceştia din urmă nu mai stau pe margine, ci sunt constrânşi să facă parte din horă: „Orchestra începe o horă răpide; toți se prind la joc împregiurul lui Lunătescu și a Tarsiței”. La fel ca eroii din Iorgu de la Sadagura, Lunătescu și Tarsița sunt tot personaje pe care autorul a vrut să le izoleze din corpul comunității. Se poate însă observa că hora acționează ca un dispozitiv coercitiv, care forțează includerea. Dansul e pornit ca o formă de putere exercitată asupra eroilor neintegrați: „Hora măi, împregiurul cucoanii Tarsiții... hora pe zdravân” spune cel care lansează mișcarea, adăugând puțin mai jos: „Hora măi, vârtos, vârtos!". Ultima indicație de scenă surprinde două mișcări concentrice, un grup mare de personaje pe exterior şi un cuplu în interior, care nu participă de 
bunăvoie, ci e reținut prin forța închiderii cercului în jurul său: „În vuietul horei, Tarsița se trezește și voiește să fugă cu Lunătescu, dar nu au pe unde" (Alecsandri VI, 135). Hora exercită aceeași funcție coercitivă în Nunta țărănească din 1848. Cel aflat în centrul dansului şi blocat de mișcarea circulară e la rândul lui antrenat într-o dinamică obligată: grecul Gaitanis e prins într-un scrânciob şi învârtit. „Ț̆ăranii încep a întoarce scrânciobul, în vreme ce cântă horul următor; Gaitanis se zbuciumă furios în scaun”. Ceea ce subliniază în plus punerea în scenă e vulnerabilitatea, eroul resimțind vertijul acestui dans pe care nu și-l dorește: „lasa se mi scoboru, che mi-a venito virtizelu la capo" (Alecsandri V, 343).

Din această perspectivă putem reciti încheierea Scrisorii pierdute, cu binecunoscuta manifestație postelectorală. Deși apărută la patruzeci de ani după finalurile cu hore ale paşoptiștilor, ea reface aceeaşi mişcare de grup cu mai multe etaje de integrare. Didascalia organizează o interacțiune bazată pe cuprinderea concentrică a mai multor dinamici diferite: „Grupurile se mișcă. Toată lumea se sărută gravitând în jurul lui Cațavencu și lui Dandanache, care se strâng în brațe, în mijloc. Dandanache face gestul cu clopoțelul. Zoe și Tipătescu contemplă de la o parte mișcarea" (Caragiale, Opere 221). Ca Alecsandri în Iorgu de la Sadagura, Caragiale ordonează mişcarea în trei planuri: Cațavencu şi Dandanache în centru, Zoe şi Tipătescu pe margine, o mulțime care se mișcă pe cercul exterior, „gravitațional”. Ce învățăm să vedem aşezând această scenă în continuitatea horelor paşoptiste e modul laborios de construcție a unei reconcilieri, care nu se sprijină nici pe liberul arbitru, nici pe capacitatea individului de „a-și căuta fericirea”. Împăcarea se realizează prin mobilizarea unei constrângeri și expunerea unei vulnerabilități. Cei care se strâng în brațe, în mijloc, sunt de două ori obligați să o facă, prin forța presiunii exterioare şi datorită propriei lor slăbiciuni. Pentru că ei se împacă sprijinindu-se de fapt reciproc: poza de final îi surprinde pe cei doi adversari cuprinşi de vertij, în starea lor cea mai instabilă și dependentă de cei din jur.

Faptul că într-un moment de maturitate a culturii comediei în spaţiul românesc Caragiale recurge la această arhitectură a reconcilierii pune problema opțiunii între forme. De ce alege ca împăcarea să se desfăşoare într-o asemenea configurație a raporturilor sociale? De ce trebuia, pentru pacificarea a doi adversari, să se mobilizeze o mulțime într-o mișcare gravitaţională în jurul lor? Într-un eseu pătrunzător, Caroline Levine vorbește, sub numele „affordance of a form”, despre posibilitățile de exploatare socială ale unei forme, despre ceea ce o societate poate să 
gândească, să proiecteze și, în cele din urmă, să realizeze cu ajutorul unei forme: „The potential uses or actions latent in materials and designs" (6). Din acest punct de vedere, nunta și hora se disting clar. Între formele pe care le enumeră Levine, nunta mobilizează potențialul ierarhiilor (85). Ea permite abordarea raportului dintre clase sociale, a raportului dintre genuri, oferă posibilitatea transgresiunii şi promite răsturnarea unor relații de dominaţie existente. Chiar dacă prin modul de utilizare în spațiul românesc căsătoria are tendința să minimizeze rolul libertății individuale, ea contribuie totuși, în continuare, la inversarea polilor unui câmp de putere. Schema ierarhică și semnificația parcurgerii ei sunt pe deplin conservate, doar că s-a schimbat agentul care provoacă această mişcare pe verticala stratificării sociale: transgresiunea dominației nu e acţionată de voința protagonistului, de elanul său de „căutare a fericirii”, ci de hazardul unui mariaj văzut ca dispozitiv suprapersonal. Hora, în schimb, implică potențialul rețelei. Ea evocă forța co-prezenței și capacitatea ei de a asocia instanțe eterogene, neutralizând tensiunile sociale. Ea evocă de asemenea posibilitatea de a se multiplica și de a articula împreună mai multe rețele, de rang, dinamici şi anvergură diferite. Şi, mai ales, evocă potențialul slăbiciunii: nu întâmplător, Levine începe capitolul despre rețele cu analiza clasică a lui Mark S. Granovetter despre forța legăturilor slabe (112). Faptul că autorul Scrisorii pierdute găsește interes în reluarea scenei etajate a horei trebuie corelat de aceea cu exploatarea formei-rețea în momente și schițe. De la lanțul slăbiciunilor, la mișcarea telegramelor în corpul social, până la contactul slab şi polivalent al lui Mitică cu ansamblul societății bucureștene, cele mai multe din împăcările pe care le imaginează Caragiale presupun utilizarea calităților unei asemenea forme a relațiilor sociale. Nu e vorba aici de angajarea personajelor într-o idilică fraternitate comunitară, ci de o dinamică mai complexă, în care fiecare acceptă puterea celuilalt asupra sa. Ceea ce repetă necontenit personajele din Lanţul slăbiciunilor, „nu e-n stare să-mi refuze nimic”, arată că rețeaua se bazează pe expunerea reciprocă a vulnerabilităţii. Fiecare îşi recunoaşte la rândul său slăbiciunea, lăsând astfel loc pentru ca puterea, influența sau autoritatea celuilalt să se manifeste, revendicându-şi totodată propria putere în acest spațiu desenat de retragerea prevenitoare a altuia. Acesta e mecanismul şi în Telegrame, cel mai important document literar al unei pacificări în secolul al 19-lea, căruia îi datorăm clișeul prin excelență al împăcării în cultura română: „Pupat toți piața endepenți” (Caragiale, Teme 240). Aici, forma rețea e singura soluție pentru obținerea reconcilierii. Pacea nu se poate realiza în doi, prin dialogul părților 
implicate direct, prin atragerea în dispută a noi actori. Ministrul Justiţiei, procurorul, Ministrul Domeniilor, prefectul. Așa funcţionează logica socială a schimbului de mesaje, ca extindere progresivă - contaminare, dacă vrem - a conflictului. În mod semnificativ, în acest fel procesul de reconciliere sfârșește prin a da câş̧tig de cauză opoziției, nu puterii, pentru că rețeaua se bazează pe cedări şi pe favoruri, pe forța cumulată a slăbiciunilor - nu pe forța brută a dominației.

$\mathrm{Nu}$ ştiu dacă putem vorbi de o evoluție între două forme ale relațiilor sociale (ierarhii și rețele) de-a lungul secolului al 19-lea, dar, în orice caz, putem atesta prin intermediul literaturii o oscilație semnificativă. Poate că a fost mai simplu pentru societatea românească să încerce astfel rezolvarea discordiei: decât să gândească transgresiuni ale categoriei sociale, strâns legate de libertatea individului şi de afirmarea voinței sale, a preferat să proiecteze moduri în care slăbiciunea poate crea solidaritate, în care comunitatea se împacă adăugând o vulnerabilitate la alta.

Reflecţia asupra deznodământului comediei ne introduce într-o dinamică a formelor situată între literatură şi societate, care presupune, pe de-o parte, cunoașterea dispozitivelor şi codurilor din tradiția genului literar, și, de cealaltă parte, înțelegerea obiectivelor morale ale unei comunități. Metodologic, trebuie să acceptăm că e imposibil să desfăşurăm o asemenea anchetă în absența unei înțelegeri a formei care să implice simultan două accepțiuni, forma relațiilor sociale şi forma literară. Că între mariaj sau horă - dispozitive preluate de scriitorii români din diverse tradiții ale genului comic - și raporturile sociale, de cuplu sau de grup, de prietenie sau de iubire, de pasiune sau de cointeresare, există o interacțiune puternică. Că între forma raporturilor maritale sau amicale posibile în societatea românească şi forma literară se țes multiple legături, se marchează afinități sau dimpotrivă se nasc tensiuni și se produc deformări. Şi că avem nevoie de dinamica transversală a unei asemenea perspective ca să înțelegem gestiunea prin literatură a distanţelor sociale, a dezgustului și a inechității în secolul al 19-lea.

\section{Referințe}

Alecsandri, Vasile. Opere. Ediție îngrijită de Georgeta Rădulescu-Dulgheru, vol. V-VI. Minerva, 1975-1979.

Caragiale, I.L. Opere. Ediție îngrijită de Al. Rosetti, Șerban Cioculescu, Liviu Călin. vol. I. ESPLA, 1957. 
Caragiale, I.L. Teme şi variațiuni. Ediție îngrijită de Ion Vartic. Dacia, 1988.

Primii noștri dramaturgi. Ediție îngrijită de Al. Niculescu. ESPLA, 1955.

Agamben, Giorgio. „Comedy.” 1978. The End of the Poem. Studies in Poetics. Translated by Daniel-Heller Roazen. Stanford UP, 1999.

Agamben, Giorgio. La Guerre Civile. Pour une théorie politique de la stasis. Traduit par Joël Gayraud. Points, 2015.

Bahtin, M. „Formele timpului şi ale cronotopului în roman.” Probleme de literatură şi estetică. Traducere de Nicolae Iliescu. Univers, 1982: 293-490.

Cavell, Stanley. Pursuit of Happiness. The Hollywood Comedy of Remarriage. Harvard UP, 1981.

Cordner, Michael. „Marriage Comedy after the 1688 Revolution: Southerne to Vanbrugh.” The Modern Language Review, vol. 85, no. 2, Apr. 1990: 273-289.

Cornea, Paul. Originile romantismului românesc. Spiritul public, mişcarea ideilor și literatura între 1780-1840. Minerva, 1972.

Fanache, V. Caragiale. 1984. Dacia, 2002.

Goffman, Erving. Stigmate. Les usages sociaux des handicaps. 1963. Traduit par Alain Kihm. Minuit, 1975.

Levine, Caroline. Forms. Whole, Rhythm, Hierarchy, Network. Princeton UP, 2015.

Loraux, Nicole. „La guerre dans la famille.” CLIO, no. 5, 1997: 21-62.

Loraux, Nicole. La tragédie d'Athènes. La politique entre l'ombre et l'utopie. Seuil, 2005 .

Mezer, Michael J. „Reflexions on Comic Reconciliations: Ethics, Memory ans Anxious Happy Endings." The Journal of Aesthetics and Art Criticism, vol. 66, no. 1, Winter 2008: 77-87.

Miller, William Ian. The Anatomy of Disgust. Harvard UP, 1997.

Nussbaum, Martha. Hiding from Humanity: Disgust, Shame, and the Law. Princeton UP, 2004.

Nussbaum, Martha. Political Emotions. Why Love Matters for Justice. Harvard UP, 2013.

Steinhardt, N. „Secretul Scrisorii pierdute.” Cartea împărtășiriii. Ediție îngrijită de Ion Vartic. Biblioteca Apostrof, 1995: 15-104.

Rodowick, D.N. „Commedy and Community.” Philolophy's Artfull Conversation. Harvard UP, 2015: 246-259. 
METACRITIC JOURNAL FOR COMPARATIVE STUDIES AND THEORY 4.2

Wheatley, Cristopher. „Romantic Love and Social Necessities: Reconsidering Justifications for Marriage in Restoration Comedy.” Restorations: Studies in English Literary Culture, vol. 14, no. 2, Fall 1990: 58-70. 